Supporting Information

\title{
Detection and Structural Investigation of Elusive Palladium Hydride Intermediates Formed from Simple Metal Salts
}

Alexander Yu. Kostyukovich, ${ }^{\dagger}$ Julia V. Burykina, ${ }^{\dagger}$ Dmitry B. Eremin, ${ }^{\dagger, t}$ Valentine P. Ananikov ${ }^{\dagger, *}$

${ }^{\dagger}$ Zelinsky institute of Organic Chemistry, Russian Academy of Sciences, Leninsky Prospect 47, Moscow 119991, Russia

*The Bridge@USC, University of Southern California, 1002 Childs Way, Los Angeles, California 90089-3502, USA 


\section{Table of contents}

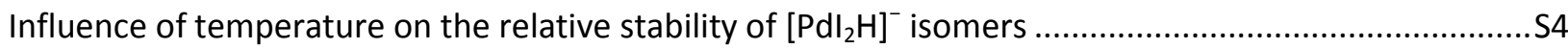

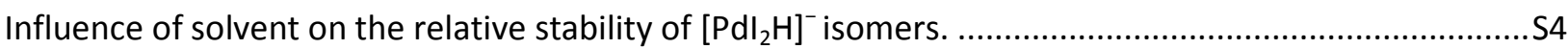

Table S1. Energies $\Delta E(\mathrm{kcal} / \mathrm{mol})$ of fragmentation reactions of $\left[\mathrm{X}_{2} \mathrm{PdH}\right]^{-}$isomers................................S6

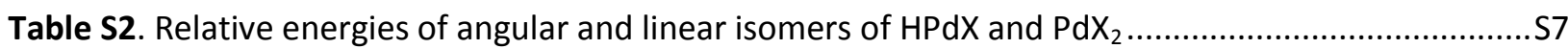

Figure S1. Energy profiles of isomerization and fragmentation reactions of $\left[\mathrm{PdCl}_{2} \mathrm{H}\right]^{-}$. Interatomic

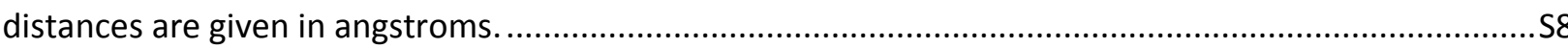

Figure S2. Energy profiles of isomerization and fragmentation reactions of $\left[\mathrm{PdBr}_{2} \mathrm{H}\right]^{-}$. Interatomic

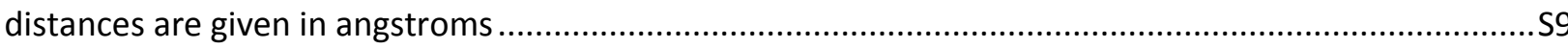

Figure S3. Energy profiles of isomerization and fragmentation reactions of $\left[\mathrm{Pdl}_{2} \mathrm{H}\right]^{-}$. Interatomic distances are given in angstroms

Figure S4. NBO charges and bond orders of $\left[\mathrm{PdCl}_{2} \mathrm{H}\right]^{-}$and $\left[\mathrm{PdBr}_{2} \mathrm{H}\right]^{-}$isomers

Table S3. Results of MD simulations for isomers $1 c-4 c$ carried out at various temperatures. Simulation time is $10 \mathrm{ps}$. Plus - reaction occured during the simulation; minus - reaction did not occurred ......S12

Table S4. Comparison of the relative energies of $\left[\mathrm{PdCl}_{2} \mathrm{H}\right]^{-}$isomers obtained in the PBE, B3LYP functionals and using CCSD/Def2TZVPP level of theory

Table S5. Comparison of the relative energies of $\left[\mathrm{PdBr}_{2} \mathrm{H}\right]^{-}$isomers obtained in the PBE, B3LYP functionals and using CCSD/Def2TZVPP level of theory

Table S6. Comparison of the relative energies of $\left[\mathrm{Pdl}_{2} \mathrm{H}\right]^{-}$isomers obtained in the PBE, B3LYP functionals and using CCSD/Def2TZVPP level of theory

Figure S5. Simulated mass spectra of $\left[\mathrm{PdX}_{2}\right]^{-}$and $\left[\mathrm{PdX}_{2} \mathrm{H}\right]^{-}$ions expanded to single digit selected isotope at High and Ultra-High resolving power.

Figure S6. Experimentally detected $\left[\mathrm{PdBr}_{2}\right]^{-} /\left[\mathrm{PdBr}_{2} \mathrm{H}\right]^{-}$signals in the mass-spectra of $\mathrm{PdBr}_{2}$ in $\mathrm{THF}$ with 10 eq $\mathrm{Et}_{3} \mathrm{~N}$ solutions and calculated patterns for fine structure analysis.

Figure S7. Experimentally detected $\left[\mathrm{Pdl}_{2}\right]^{-} /\left[\mathrm{Pdl}_{2} \mathrm{H}\right]^{-}$signals in the mass-spectra of $\mathrm{Pdl}_{2}$ in $\mathrm{THF}$ with 10 eq $\mathrm{Et}_{3} \mathrm{~N}$ solutions and calculated patterns for fine structure analysis. S15

Table S7. The signal appearance data of $\mathrm{PdX}$ solutions .$S 15$

Table S8. The signal appearance data of $\mathrm{PdX}$ solutions with one equivalent of $\mathrm{NaBH}_{4}$ S16

Table S9. The signal appearance data of $\mathrm{PdX}_{2}$ solutions with ten equivalents of $\mathrm{Et}_{3} \mathrm{~N}$ S16

Figure S8. Extracted ion curves for the real-time abundances of ions in the Mizoroki-Heck reaction between butyl acrylate and iodobenzene in $\mathrm{DMF}\left(\mathrm{K}_{2} \mathrm{CO}_{3}\right.$ as base) catalyzed by $\mathrm{PdCl}_{2}(0.44 \mathrm{~mol} \%$ ) (Table

2, Entry 1). S16

Figure 59. Extracted ion curves for the real-time abundance of ion in the Mizoroki-Heck reaction between butyl acrylate and iodobenzene in $\mathrm{DMF}\left(\mathrm{K}_{2} \mathrm{CO}_{3}\right.$ as base) catalyzed by $\mathrm{Pdl}_{2}(0.44 \mathrm{~mol} \%)$ ( $\mathrm{Table}_{2}$, Entry 2).

Figure S10. Extracted ion curves for the real-time abundance of ion in the Mizoroki-Heck reaction between butyl acrylate and iodobenzene in $\mathrm{DMF}\left(\mathrm{K}_{2} \mathrm{CO}_{3}\right.$ as base) catalyzed by $\mathrm{Pd}_{2} \mathrm{dba}_{3}(0.44 \mathrm{~mol} \%)$ (Table 2, Entry 3).

Figure S11. Extracted ion curves for the real-time abundance of ion in the Mizoroki-Heck reaction between butyl acrylate and iodobenzene in $\mathrm{DMF}\left(\mathrm{K}_{2} \mathrm{CO}_{3}\right.$ as base) catalyzed by $\mathrm{Pd}(\mathrm{OAc})_{2}(0.44 \mathrm{~mol} \%)$ (Table 2, Entry 4). 
Figure S12. Extracted ion curves for the real-time abundance of ion in the Mizoroki-Heck reaction between butyl acrylate and bromobenzene in $\mathrm{DMF}\left(\mathrm{K}_{2} \mathrm{CO}_{3}\right.$ as base) catalyzed by $\mathrm{Pd}_{2} \mathrm{dba}_{3}(0.44 \mathrm{~mol} \%)$ (Table 2, Entry 7).

Figure S13. Extracted ion curves for the real-time abundance of ion in the Mizoroki-Heck reaction between butyl acrylate and iodobenzene in toluene $\left(\mathrm{K}_{2} \mathrm{CO}_{3}\right.$ as base) catalyzed by $\mathrm{Pd}_{2} \mathrm{dba}_{3}(0.44 \mathrm{~mol} \%)$ (Table 2, Entry 9)

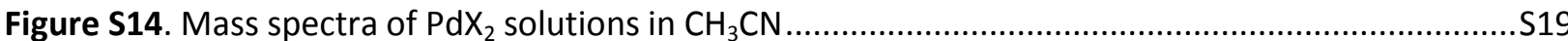

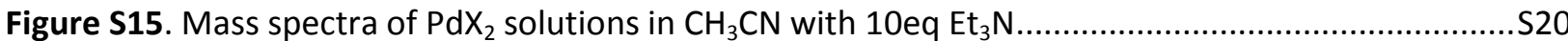

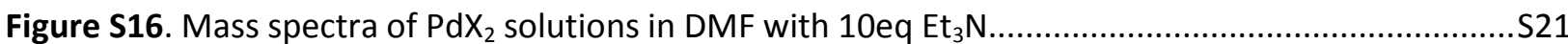

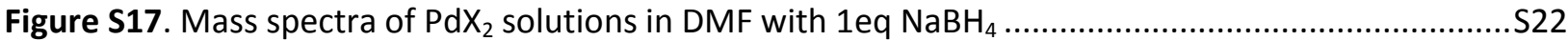

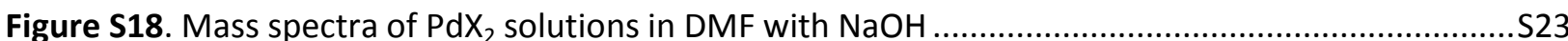

Figure S19. Sources of the hydrogen atom in the process of activation of the precatalyst and in the Heck reaction 
Influence of temperature on the relative stability of $\left[\mathrm{PdI}_{2} \mathrm{H}\right]^{-}$isomers. Temperature can affect the relative stability of $\left[\mathrm{Pd}(\mathrm{H}) \mathrm{I}_{2}\right]^{-}$structures, if the entropy difference between the isomers is high. The entropy contribution (T $\Delta \mathrm{S})$ to the relative energy $\Delta \mathrm{G}$ of the isomer is given by the equation $\Delta \mathrm{G}=\Delta \mathrm{H}-\mathrm{T} \Delta \mathrm{S}$. Knowing the values of entropy for complexes 1c - 4c, we can calculate what is the contribution of the entropy factor to the change in the relative energies of isomers on going from $300 \mathrm{~K}$ to $1000 \mathrm{~K}$ (see table below).

\begin{tabular}{|c|c|c|c|c|c|}
\hline Isomer & $\mathrm{S}, \mathrm{kal} /\left(\mathrm{mol}^{*} \mathrm{~K}\right)$ & $\begin{array}{c}\Delta \mathrm{S}, \\
\mathrm{kal} /\left(\mathrm{mol}^{*} \mathrm{~K}\right)\end{array}$ & $\begin{array}{c}\mathrm{T}^{300 \mathrm{~K}} \Delta \mathrm{S}, \\
\mathrm{kcal} / \mathrm{mol}\end{array}$ & $\begin{array}{c}\mathrm{T}^{1000 \mathrm{~K}} \Delta \mathrm{S}, \\
\mathrm{kcal} / \mathrm{mol}\end{array}$ & $\begin{array}{c}\left(\mathrm{T}^{300 \mathrm{~K}} \Delta \mathrm{S}-\mathrm{T}^{1000 \mathrm{~K}} \Delta \mathrm{S}\right), \\
\mathrm{kcal} / \mathrm{mol}\end{array}$ \\
\hline 1c & 85.658 & 0 & 0 & 0 & 0 \\
\hline 2c & 86.274 & 0.616 & 0.18 & 0.62 & -0.44 \\
\hline 3c & 88.361 & 2.703 & 0.81 & 2.70 & -1.89 \\
\hline 4c & 88.507 & 2.849 & 0.85 & 2.85 & -2.00 \\
\hline
\end{tabular}

From the table, we see that, due to the entropy factor, with an increase in temperature from $300 \mathrm{~K}$ to $1000 \mathrm{~K}$, a slight stabilization of complexes $\mathbf{2 c}-\mathbf{4 c}$ occurs. The energy of $\mathbf{4 c}$ changes to a greater extent (it decreases by $2.04 \mathrm{kcal} / \mathrm{mol}$ ), since this structure has the highest entropy. Nevertheless, these changes are relatively small and do not change the stability series of the $\left[\mathrm{Pd}(\mathrm{H}) \mathrm{I}_{2}\right]^{-}$isomers.

Influence of solvent on the relative stability of $\left[\mathrm{PdI}_{2} \mathbf{H}\right]^{-}$isomers. The isomers of $\left[\mathrm{PdI}_{2} \mathrm{H}\right]^{-}$were calculated using the PCM continuum model to assess the solvent effect. We took DMF as a solvent, which has the highest dielectric constant $(\varepsilon=37.219)$ among the solvents used in our experiments. The calculation results are shown in the table below.

\begin{tabular}{|c|c|c|}
\hline Isomer & $\begin{array}{c}\Delta \mathrm{E}, \mathrm{kcal} / \mathrm{mol} \\
\text { gas phase }\end{array}$ & $\begin{array}{c}\Delta \mathrm{E}, \mathrm{kcal} / \mathrm{mol} \\
\mathrm{PCM}(\mathrm{DMF}) \text { model }\end{array}$ \\
\hline 1c & 0 & 0 \\
\hline 2c & 35.0 & 31.7 \\
\hline 3c & 38.1 & 27.8 \\
\hline 4c & 48.0 & 48.3 \\
\hline
\end{tabular}

According to the data obtained, the polar solvent significantly stabilizes the 3c structure in comparison with the other $\left[\mathrm{PdI}_{2} \mathrm{H}\right]^{-}$isomers. This compound ranks second in the order 
of stability after the T-shaped structure 1c. As in the case of the gas phase, when using the PCM model, a large difference in the energies of the two most stable isomers of $\left[\mathrm{PdI}_{2} \mathrm{H}\right]^{-}$is preserved, amounting to $27.8 \mathrm{kcal} / \mathrm{mol}$. Thus, during the transition from the gas phase to the condensed phase, the $\mathbf{1 c}$ isomer remains much more stable than the $\mathbf{2 c}$ $4 \mathbf{c}$ structures. 
Table S1. Energies $\Delta \mathrm{E}(\mathrm{kcal} / \mathrm{mol})$ of fragmentation reactions of $\left[\mathrm{X}_{2} \mathrm{PdH}\right]^{-}$isomers

\begin{tabular}{|c|c|c|}
\hline Compound & Fragmentation products & $\Delta \mathrm{E}$ \\
\hline \multirow{3}{*}{$1 \mathbf{a}$} & {$[\mathrm{ClPd}]^{-}+\mathrm{HCl}$} & 58.8 \\
\hline & $\mathrm{ClPdH}+\mathrm{Cl}^{-}$ & 72.8 \\
\hline & {$[\mathrm{HPd}]^{-}+\mathrm{Cl}_{2}$} & 128.3 \\
\hline \multirow{3}{*}{$\mathbf{2 a}$} & {$[\mathrm{ClPd}]^{-}+\mathrm{HCl}$} & 23.2 \\
\hline & $\mathrm{ClPdH}+\mathrm{Cl}^{-}$ & 37.2 \\
\hline & {$[\mathrm{HPd}]^{-}+\mathrm{Cl}_{2}$} & 92.7 \\
\hline \multirow{3}{*}{$\mathbf{3 a}$} & {$[\mathrm{ClPd}]^{-}+\mathrm{HCl}$} & 5.9 \\
\hline & $\mathrm{ClPdH}+\mathrm{Cl}^{-}$ & 19.9 \\
\hline & {$[\mathrm{HPd}]^{-}+\mathrm{Cl}_{2}$} & 75.4 \\
\hline \multirow{3}{*}{$4 \mathbf{a}$} & {$[\mathrm{ClPd}]^{-}+\mathrm{HCl}$} & 20.1 \\
\hline & $\mathrm{ClPdH}+\mathrm{Cl}^{-}$ & 34.1 \\
\hline & {$[\mathrm{HPd}]^{-}+\mathrm{Cl}_{2}$} & 89.6 \\
\hline \multirow{3}{*}{$\mathbf{1 b}$} & {$[\mathrm{BrPd}]^{-}+\mathrm{HBr}$} & 63.9 \\
\hline & $\mathrm{BrPdH}+\mathrm{Br}^{-}$ & 65.5 \\
\hline & {$[\mathrm{HPd}]^{-}+\mathrm{Br}_{2}$} & 123.9 \\
\hline \multirow{3}{*}{$2 \mathbf{b}$} & {$[\mathrm{BrPd}]^{-}+\mathrm{HBr}$} & 26.5 \\
\hline & $\mathrm{BrPdH}+\mathrm{Br}^{-}$ & 28.1 \\
\hline & {$[\mathrm{HPd}]^{-}+\mathrm{Br}_{2}$} & 86.5 \\
\hline \multirow{3}{*}{$\mathbf{3 b}$} & {$[\mathrm{BrPd}]^{-}+\mathrm{HBr}$} & 18.2 \\
\hline & $\mathrm{BrPdH}+\mathrm{Br}^{-}$ & 19.8 \\
\hline & {$[\mathrm{HPd}]^{-}+\mathrm{Br}_{2}$} & 78.2 \\
\hline \multirow{3}{*}{$4 b$} & {$[\mathrm{BrPd}]^{-}+\mathrm{HBr}$} & 19.6 \\
\hline & $\mathrm{BrPdH}+\mathrm{Br}^{-}$ & 21.2 \\
\hline & {$[\mathrm{HPd}]^{-}+\mathrm{Br}_{2}$} & 79.6 \\
\hline \multirow{3}{*}{ 1c } & {$[\mathrm{IPd}]^{-}+\mathrm{HI}$} & 66.9 \\
\hline & $\mathrm{IPdH}+\mathrm{I}^{-}$ & 58.9 \\
\hline & {$[\mathrm{HPd}]^{-}+\mathrm{I}_{2}$} & 115.2 \\
\hline \multirow{3}{*}{$2 \mathrm{c}$} & {$[\mathrm{IPd}]^{-}+\mathrm{HI}$} & 31.9 \\
\hline & $\mathrm{IPdH}+\mathrm{I}^{-}$ & 23.9 \\
\hline & {$[\mathrm{HPd}]^{-}+\mathrm{I}_{2}$} & 80.2 \\
\hline \multirow{3}{*}{$3 c$} & {$[\mathrm{IPd}]^{-}+\mathrm{HI}$} & 28.8 \\
\hline & $\mathrm{IPdH}+\mathrm{I}^{-}$ & 20.8 \\
\hline & {$[\mathrm{HPd}]^{-}+\mathrm{I}_{2}$} & 77.1 \\
\hline \multirow{3}{*}{$4 c$} & {$[\mathrm{IPd}]^{-}+\mathrm{HI}$} & 18.9 \\
\hline & $\mathrm{IPdH}+\mathrm{I}^{-}$ & 10.9 \\
\hline & {$[\mathrm{HPd}]^{-}+\mathrm{I}_{2}$} & 67.2 \\
\hline
\end{tabular}


Table S2. Relative energies of angular and linear isomers of HPdX and $\mathrm{PdX} \mathrm{X}_{2}$

\begin{tabular}{|c|c|c|}
\hline Complexc & Structuree & $\begin{array}{c}\text { Energy, } \\
\text { Kcal/mol }\end{array}$ \\
\hline \multirow{2}{*}{$\mathrm{PdCl}_{2}$} & angular & 0 \\
\cline { 2 - 3 } & linear & 11.3 \\
\hline \multirow{2}{*}{$\mathrm{HPdCl}$} & angular & 0 \\
\cline { 2 - 3 } & linear & 32.1 \\
\hline \multirow{2}{*}{$\mathrm{PdBr}_{2}$} & angular & 0 \\
\cline { 2 - 3 } & linear & 15.3 \\
\hline \multirow{2}{*}{$\mathrm{HPdBr}$} & angular & 0 \\
\cline { 2 - 3 } & linear & 26.8 \\
\hline \multirow{2}{*}{$\mathrm{PdI}_{2}$} & angular & 0 \\
\cline { 2 - 3 } & linear & 16.3 \\
\hline \multirow{2}{*}{$\mathrm{HPdI}$} & angular & 0 \\
\cline { 2 - 3 } & linear & 31.7 \\
\hline
\end{tabular}




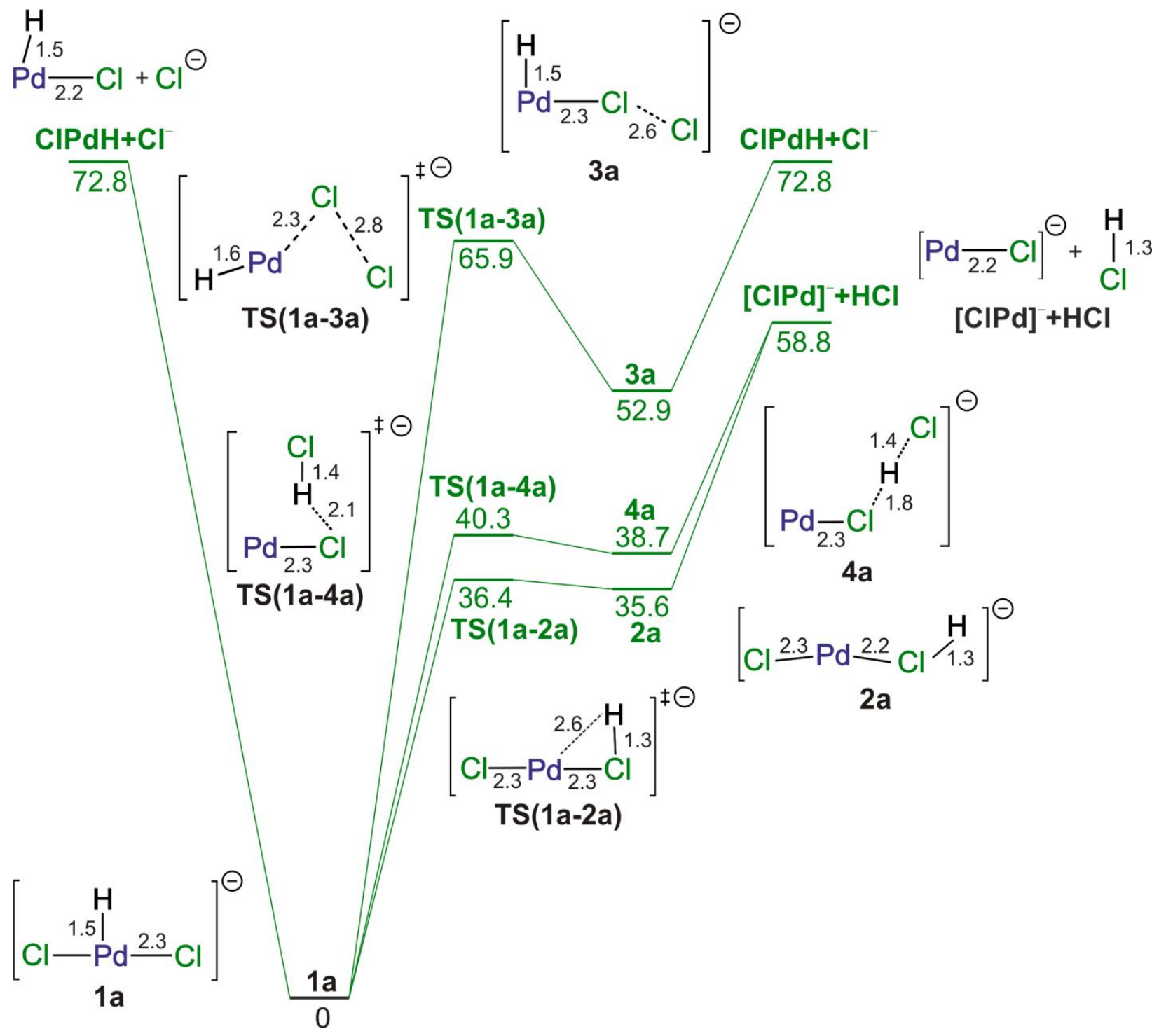

Figure S1. Energy profiles of isomerization and fragmentation reactions of $\left[\mathrm{PdCl}_{2} \mathrm{H}\right]^{-}$. Interatomic distances are given in angstroms. 


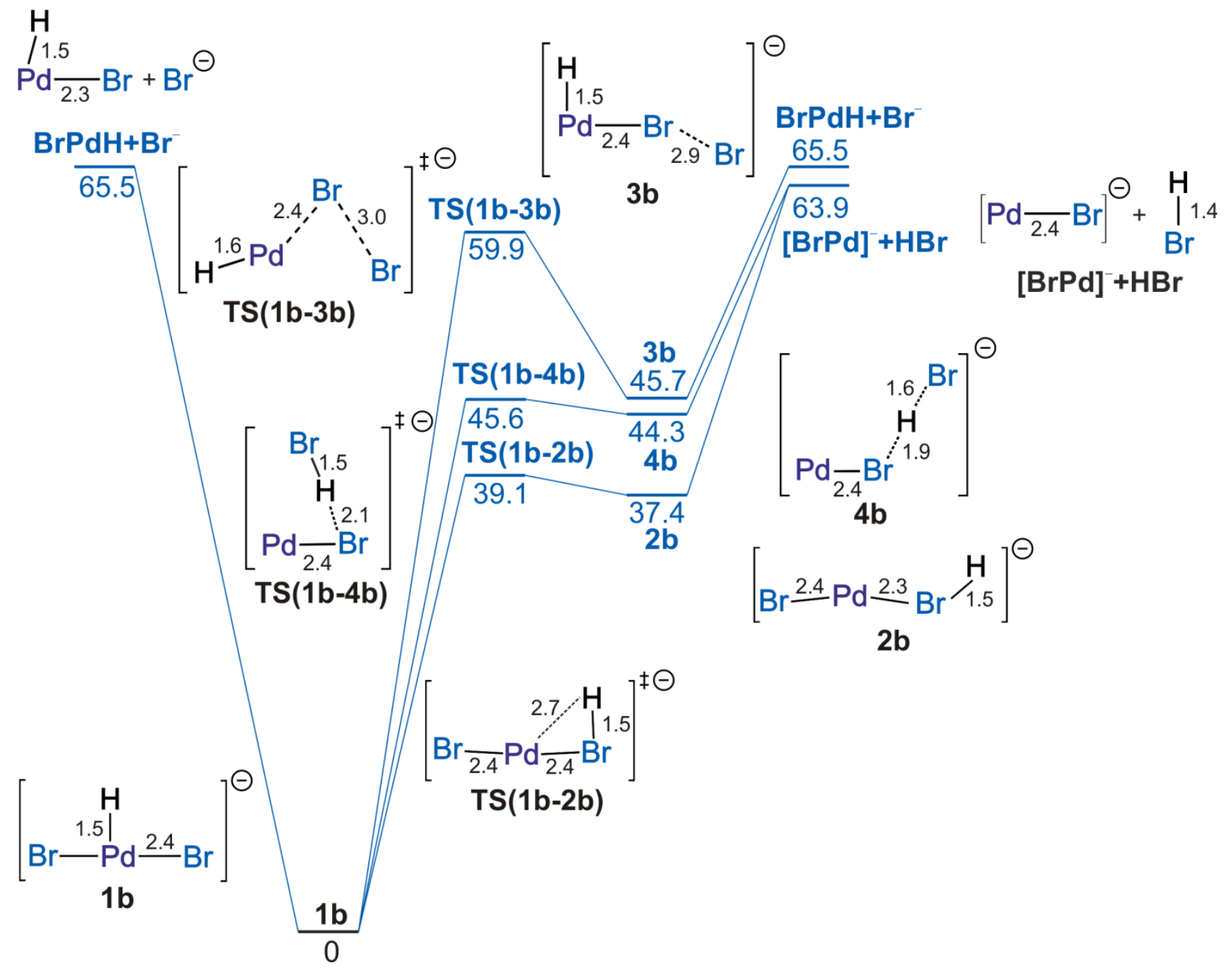

Figure S2. Energy profiles of isomerization and fragmentation reactions of $\left[\mathrm{PdBr}_{2} \mathrm{H}\right]^{-}$. Interatomic distances are given in angstroms. 


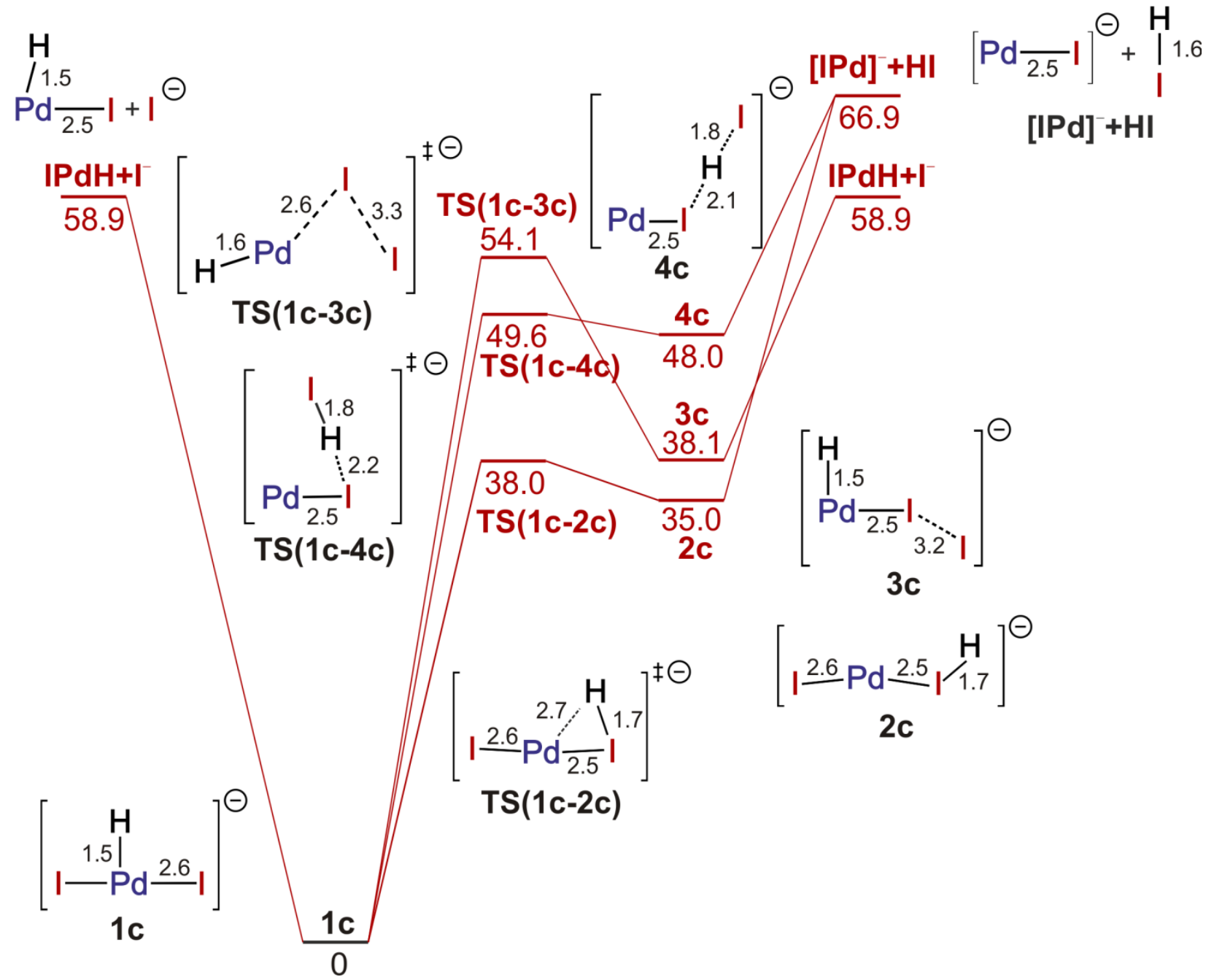

Figure S3. Energy profiles of isomerization and fragmentation reactions of $\left[\mathrm{PdI}{ }_{2} \mathrm{H}\right]^{-}$. Interatomic distances are given in angstroms. 


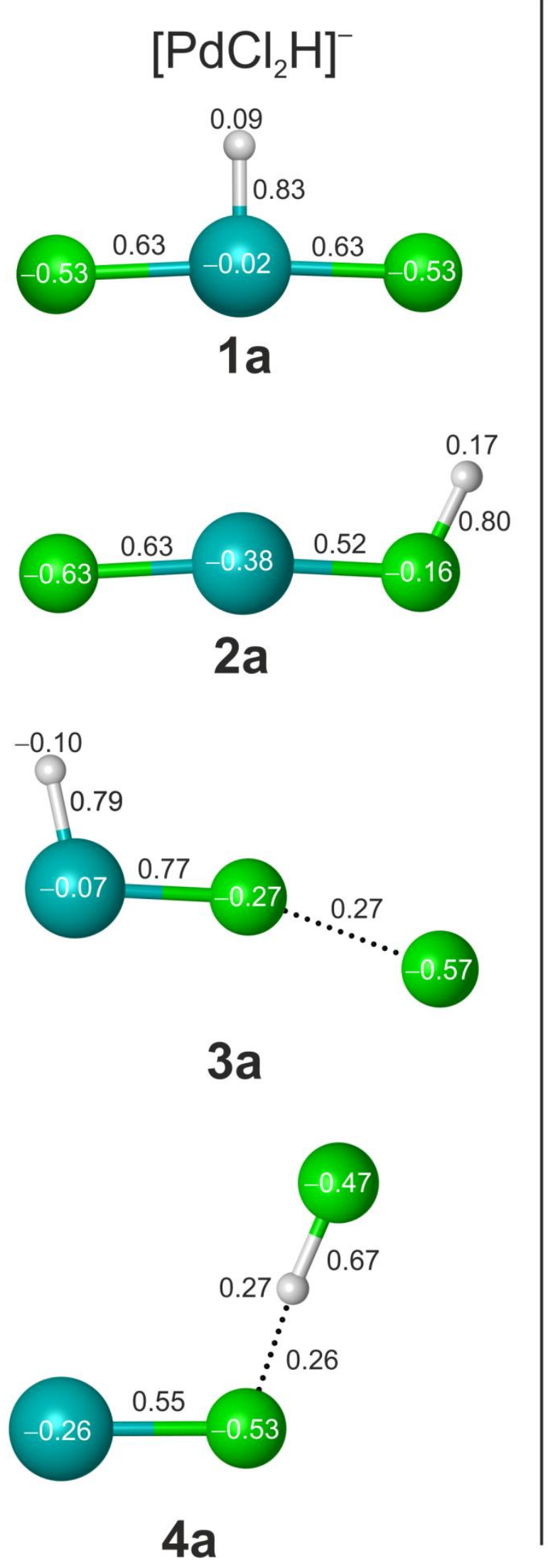

\section{$\left[\mathrm{PdBr}_{2} \mathrm{H}\right]^{-}$}
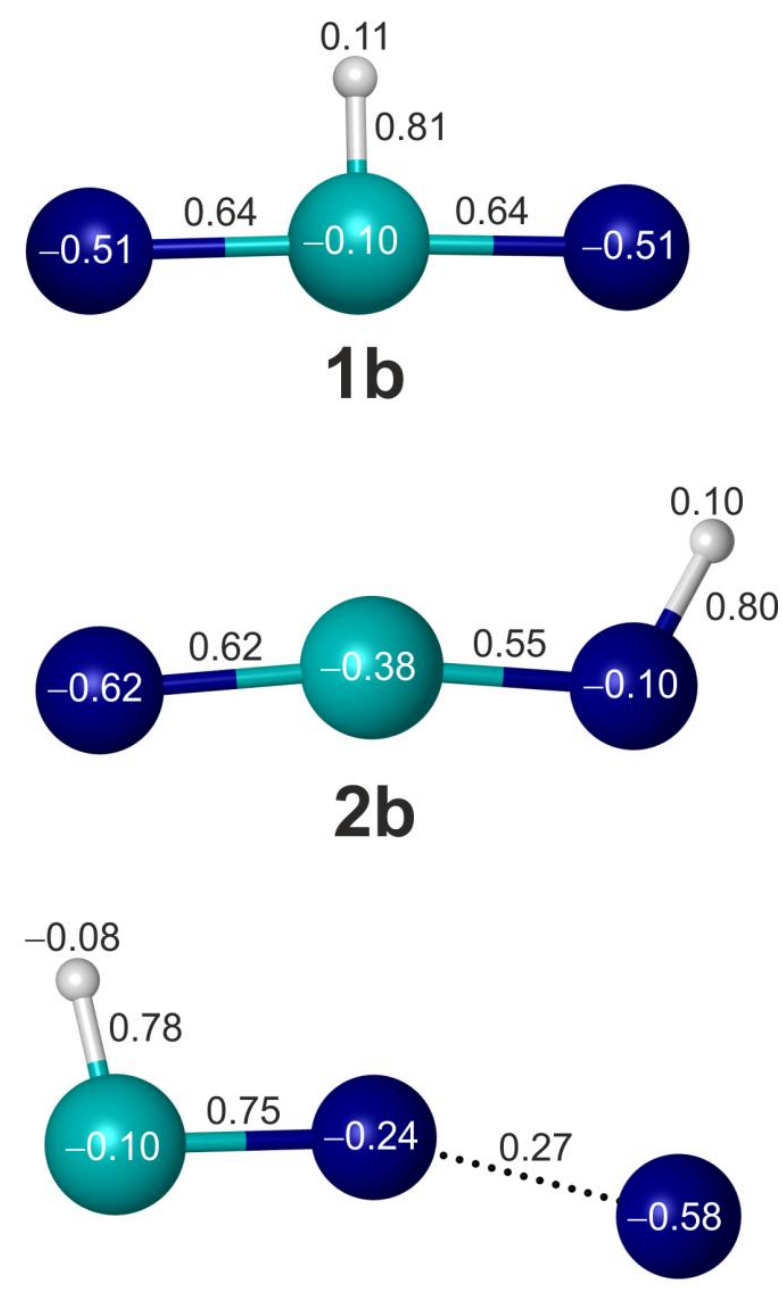

$3 b$

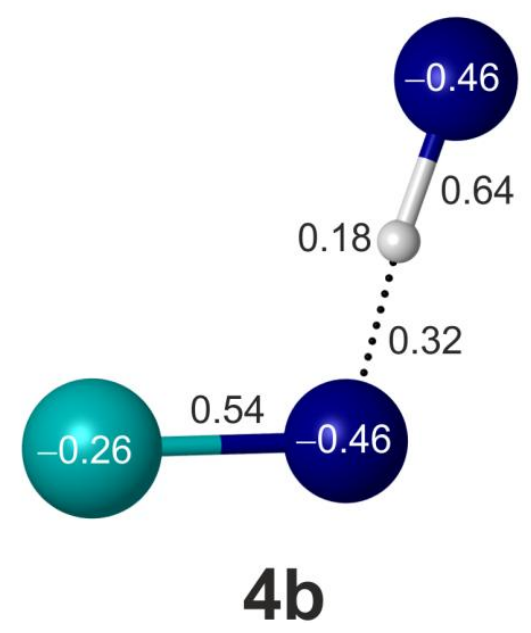

Figure S4. NBO charges and bond orders of $\left[\mathrm{PdCl}_{2} \mathrm{H}\right]^{-}$and $\left[\mathrm{PdBr}_{2} \mathrm{H}\right]^{-}$isomers. 
Table S3. Results of MD simulations for isomers $1 \mathbf{c}-\mathbf{4 c}$ carried out at various temperatures. Simulation time is 10 ps. Plus - reaction occured during the simulation; minus - reaction did not occurred

\begin{tabular}{|c|c|c|c|c|}
\hline \multirow{2}{*}{ Temperature } & \multicolumn{4}{|c|}{ Isomer } \\
\cline { 2 - 5 } & $\mathbf{1 c}$ & $\mathbf{2 c}$ & $\mathbf{3 c}$ & $\mathbf{4 c}$ \\
\hline $300 \mathrm{~K}$ & - & - & - & - \\
\hline $400 \mathrm{~K}$ & - & - & - & + \\
\hline $500 \mathrm{~K}$ & - & + & - & \\
\hline $600 \mathrm{~K}$ & - & & - & \\
\hline $700 \mathrm{~K}$ & - & & - & \\
\hline $800 \mathrm{~K}$ & - & & - & \\
\hline $900 \mathrm{~K}$ & - & & + & \\
\hline $1000 \mathrm{~K}$ & - & & \multicolumn{3}{c}{} \\
\hline
\end{tabular}

Table S4. Comparison of the relative energies of $\left[\mathrm{PdCl}_{2} \mathrm{H}\right]^{-}$isomers obtained in the $\mathrm{PBE}$, B3LYP functionals and using CCSD/Def2TZVPP level of theory

\begin{tabular}{|c|c|c|c|c|}
\hline & $\mathbf{1 a}$ & $\mathbf{2 a}$ & $\mathbf{3 a}$ & $\mathbf{4 a}$ \\
\hline PBE/Def2TZVP & 0 & 35.6 & 52.9 & 38.7 \\
\hline B3LYP/Def2TZVP & 0 & 36.9 & 59.1 & 35.9 \\
\hline CCSD/Def2TZVPP & 0 & 38.6 & 73.0 & 37.0 \\
\hline
\end{tabular}

Table S5. Comparison of the relative energies of $\left[\mathrm{PdBr}_{2} \mathrm{H}\right]^{-}$isomers obtained in the $\mathrm{PBE}$, B3LYP functionals and using CCSD/Def2TZVPP level of theory

\begin{tabular}{|c|c|c|c|c|}
\hline & $\mathbf{1 b}$ & $\mathbf{2 b}$ & $\mathbf{3 b}$ & $\mathbf{4 b}$ \\
\hline PBE/Def2TZVP & 0 & 37.4 & 45.7 & 44.3 \\
\hline B3LYP/Def2TZVP & 0 & 39.0 & 50.7 & 41.8 \\
\hline CCSD/Def2TZVPP & 0 & 40.4 & 63.0 & 43.5 \\
\hline
\end{tabular}

Table S6. Comparison of the relative energies of $\left[\mathrm{PdI}_{2} \mathrm{H}\right]^{-}$isomers obtained in the PBE, B3LYP functionals and using CCSD/Def2TZVPP level of theory

\begin{tabular}{|c|c|c|c|c|}
\hline & 1c & 2c & 3c & 4c \\
\hline PBE/Def2TZVP & 0 & 35.0 & 38.1 & 48.0 \\
\hline B3LYP/Def2TZVP & 0 & 36.3 & 41.6 & 45.9 \\
\hline CCSD/Def2TZVPP & 0 & 37.6 & 51.8 & 48.7 \\
\hline
\end{tabular}



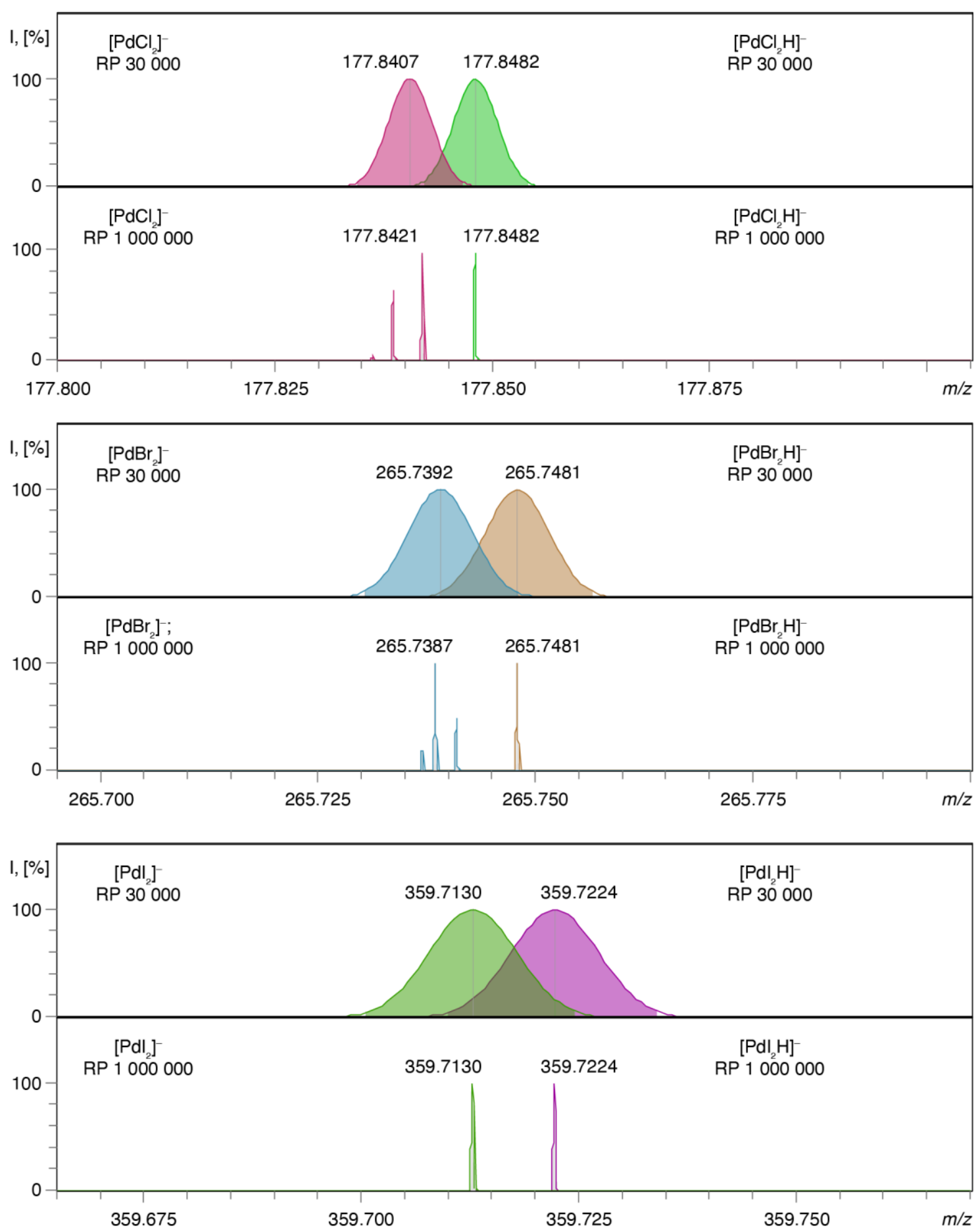

Figure S5. Simulated mass spectra of $\left[\mathrm{PdX}_{2}\right]^{-}$and $\left[\mathrm{PdX}{ }_{2} \mathrm{H}\right]^{-}$ions expanded to single digit selected isotope at High and Ultra-High resolving power. 


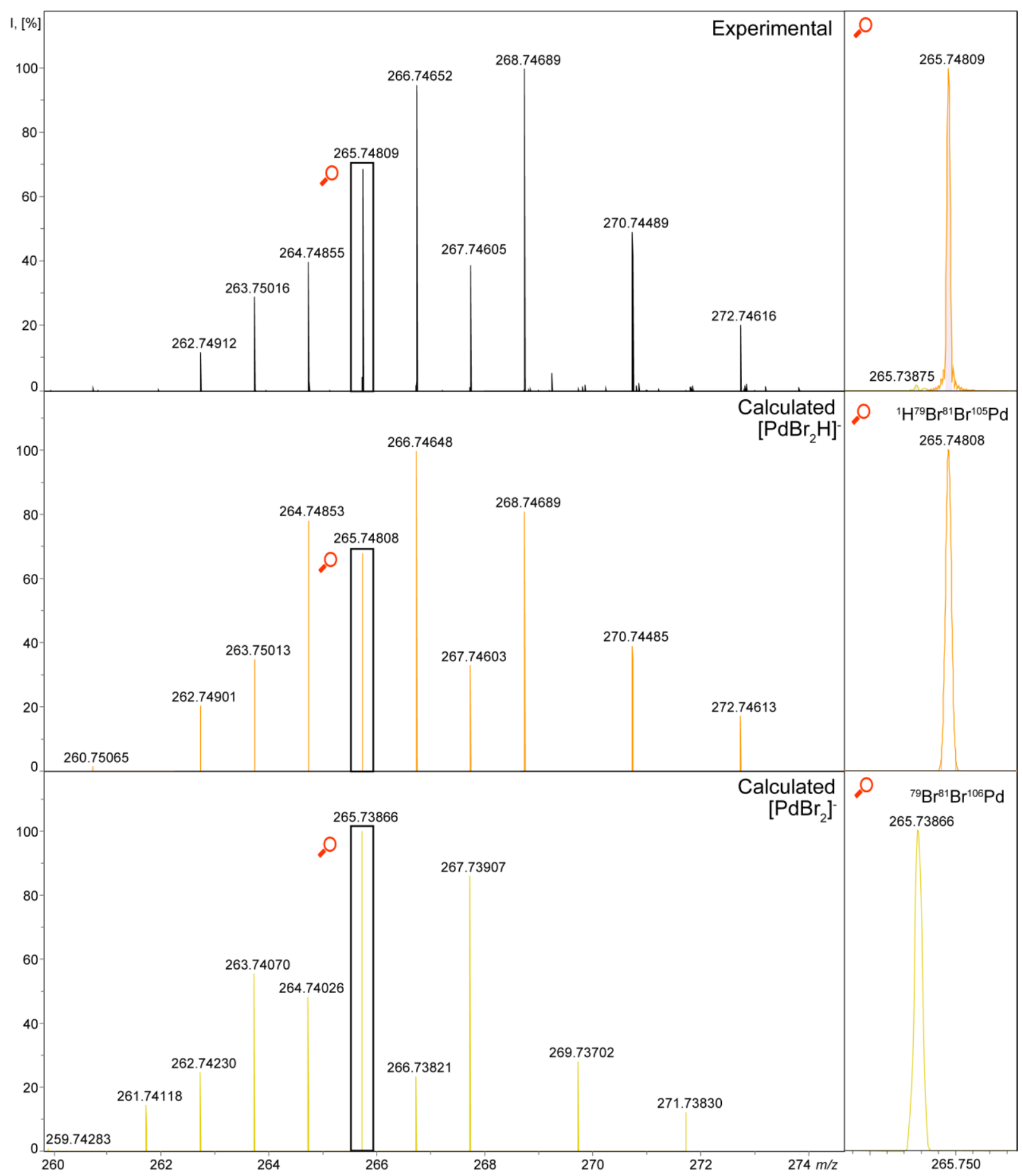

Figure S6. Experimentally detected $\left[\mathrm{PdBr}_{2}\right]^{-} /\left[\mathrm{PdBr}_{2} \mathrm{H}\right]^{-}$signals in the mass-spectra of $\mathrm{PdBr}_{2}$ in $\mathrm{THF}$ with $10 \mathrm{eq} \mathrm{Et}_{3} \mathrm{~N}$ solutions and calculated patterns for fine structure analysis. 


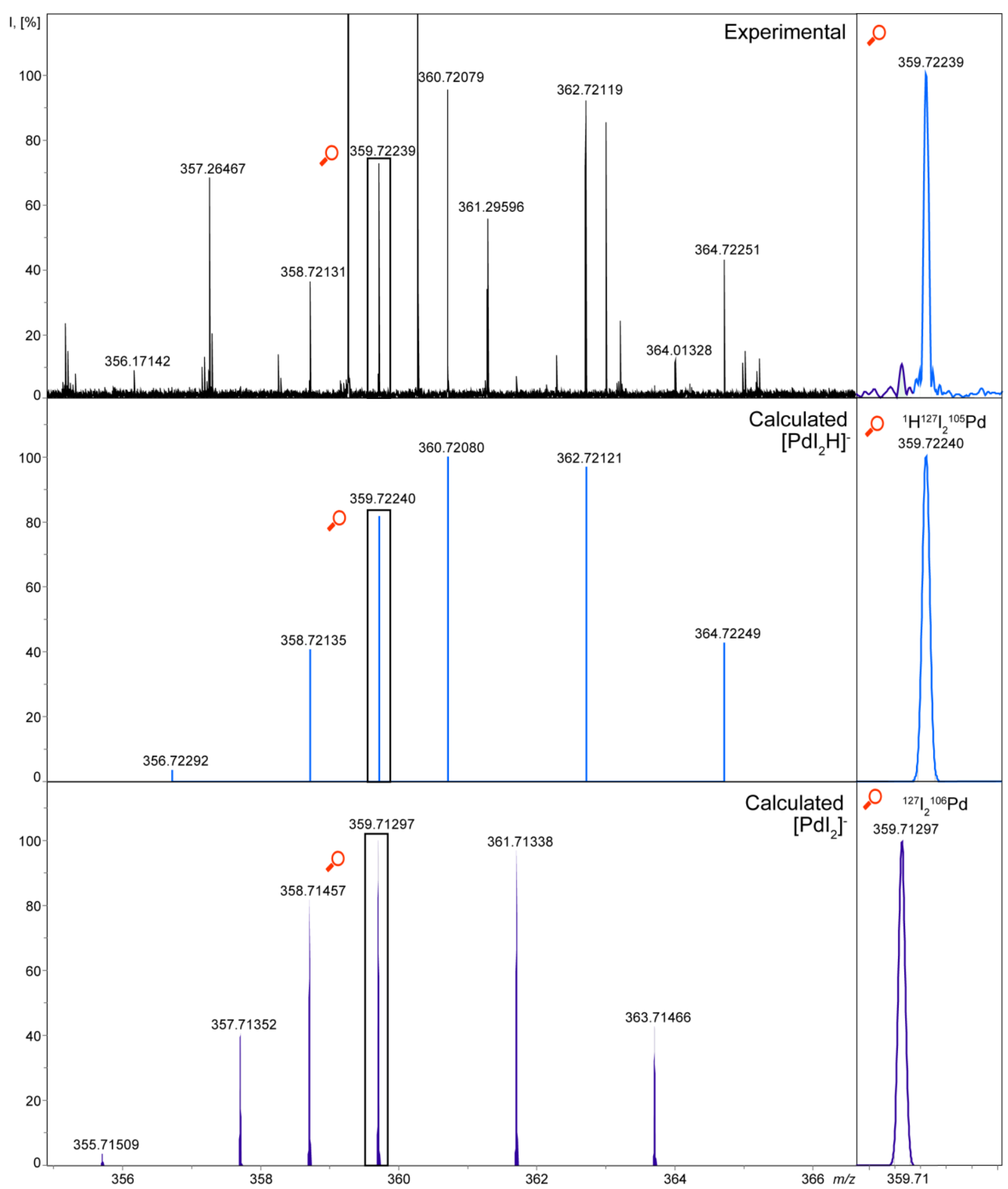

Figure S7. Experimentally detected $\left[\mathrm{PdI}_{2}\right]^{-} /\left[\mathrm{PdI}_{2} \mathrm{H}\right]^{-}$signals in the mass-spectra of $\mathrm{PdI}_{2}$ in THF with $10 \mathrm{eq} \mathrm{Et}_{3} \mathrm{~N}$ solutions and calculated patterns for fine structure analysis.

Table S7. The signal appearance data of $\mathrm{PdX}$ solutions

\begin{tabular}{|c|c|c|c|}
\hline Solvent & {$\left[\mathrm{PdCl}_{2}\right]^{-} /\left[\mathrm{PdCl}_{2} \mathrm{H}\right]^{-}$} & {$\left[\mathrm{PdBr}_{2}\right]^{-} /\left[\mathrm{PdBr}_{2} \mathrm{H}\right]^{-}$} & {$\left[\mathrm{PdI}_{2}\right]^{-} /\left[\mathrm{PdI}_{2} \mathrm{H}\right]^{-}$} \\
\hline $\mathrm{CH}_{3} \mathrm{CN}$ & $+/-$ & $+/-$ & $+/-$ \\
\hline $\mathrm{MeOH}$ & $+/+$ & $+/+(+/+)^{\mathrm{a}}$ & $-/-(+/+)^{\mathrm{a}}$ \\
\hline $\mathrm{DMF}$ & $+/+$ & $+/-$ & $+/-$ \\
\hline THF & $-/-$ & $-/-$ & $-/-$ \\
\hline
\end{tabular}

${ }^{a}$ Detected signals of two complexes after 5 days at the air. Plus - the signal was detected. Minus - the signal wasn't detected. 
Table S8. The signal appearance data of $\mathrm{PdX}_{2}$ solutions with one equivalent of $\mathrm{NaBH}_{4}$

\begin{tabular}{|c|c|c|c|}
\hline Solvent & {$\left[\mathrm{PdCl}_{2}\right]^{-} /\left[\mathrm{HPdCl}_{2}\right]^{-}$} & {$\left[\mathrm{PdBr}_{2}\right]^{-} /\left[\mathrm{HPdBr}_{2}\right]^{-}$} & {$\left[\mathrm{PdI}_{2}\right]^{-} /\left[\mathrm{HPdI}_{2}\right]^{-}$} \\
\hline $\mathrm{CH}_{3} \mathrm{CN}$ & $-/-$ & $-/-$ & $-/-$ \\
\hline $\mathrm{MeOH}$ & $+/+$ & $-/-$ & $-/-$ \\
\hline $\mathrm{DMF}$ & $+/+$ & $+/-$ & $+/-$ \\
\hline
\end{tabular}

Table S9. The signal appearance data of $\mathrm{PdX}_{2}$ solutions with ten equivalents of $\mathrm{Et}_{3} \mathrm{~N}$

\begin{tabular}{|c|c|c|c|}
\hline Solvent & {$\left[\mathrm{PdCl}_{2}\right]^{-} /\left[\mathrm{HPdCl}_{2}\right]^{-}$} & {$\left[\mathrm{PdBr}_{2}\right]^{-} /\left[\mathrm{HPdBr}_{2}\right]^{-}$} & {$\left[\mathrm{PdI}_{2}\right]^{-} /\left[\mathrm{HPdI}_{2}\right]^{-}$} \\
\hline $\mathrm{CH}_{3} \mathrm{CN}$ & $+/-$ & $+/+$ & $+/+$ \\
\hline THF & $+/+$ & $+/+$ & $+/+$ \\
\hline DMF & $+/+$ & $+/+$ & $+/+$ \\
\hline
\end{tabular}

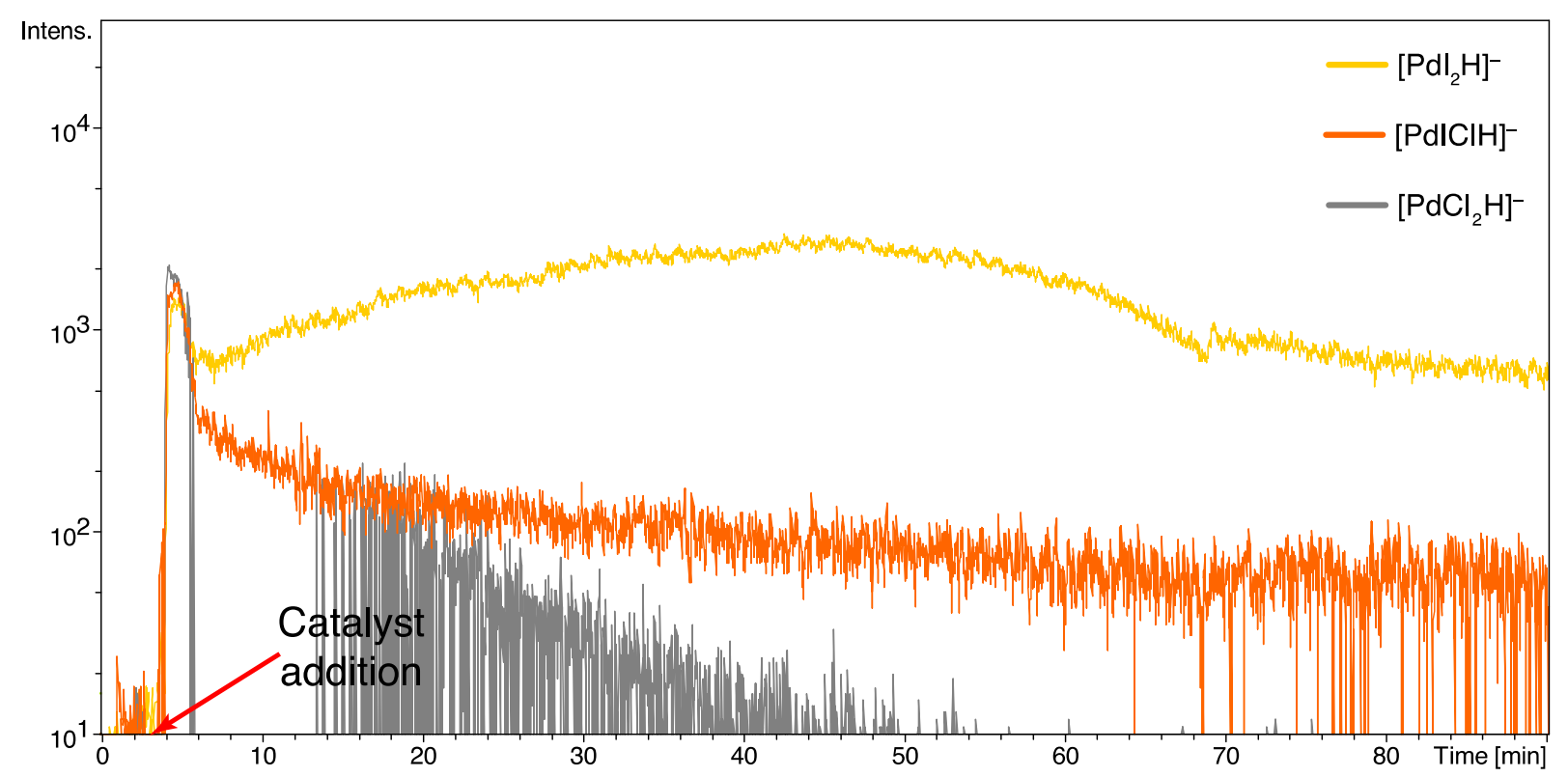

Figure S8. Extracted ion curves for the real-time abundances of ions in the MizorokiHeck reaction between butyl acrylate and iodobenzene in DMF $\left(\mathrm{K}_{2} \mathrm{CO}_{3}\right.$ as base) catalyzed by $\mathrm{PdCl}_{2}(0.44 \mathrm{~mol} \%)$ (Table 2, Entry 1$)$.

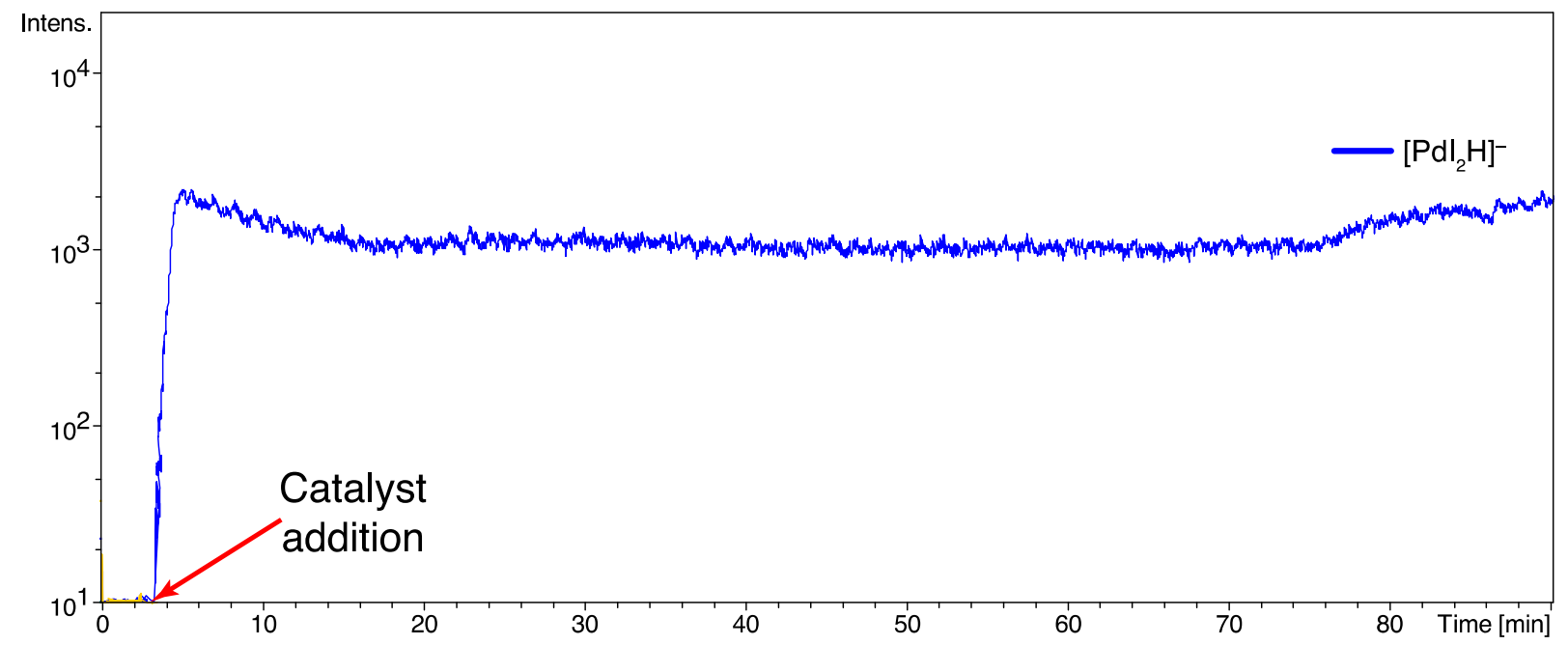

Figure S9. Extracted ion curves for the real-time abundance of ion in the Mizoroki-Heck 
reaction between butyl acrylate and iodobenzene in $\mathrm{DMF}\left(\mathrm{K}_{2} \mathrm{CO}_{3}\right.$ as base) catalyzed by $\mathrm{PdI}_{2}(0.44 \mathrm{~mol} \%)$ (Table 2, Entry 2).

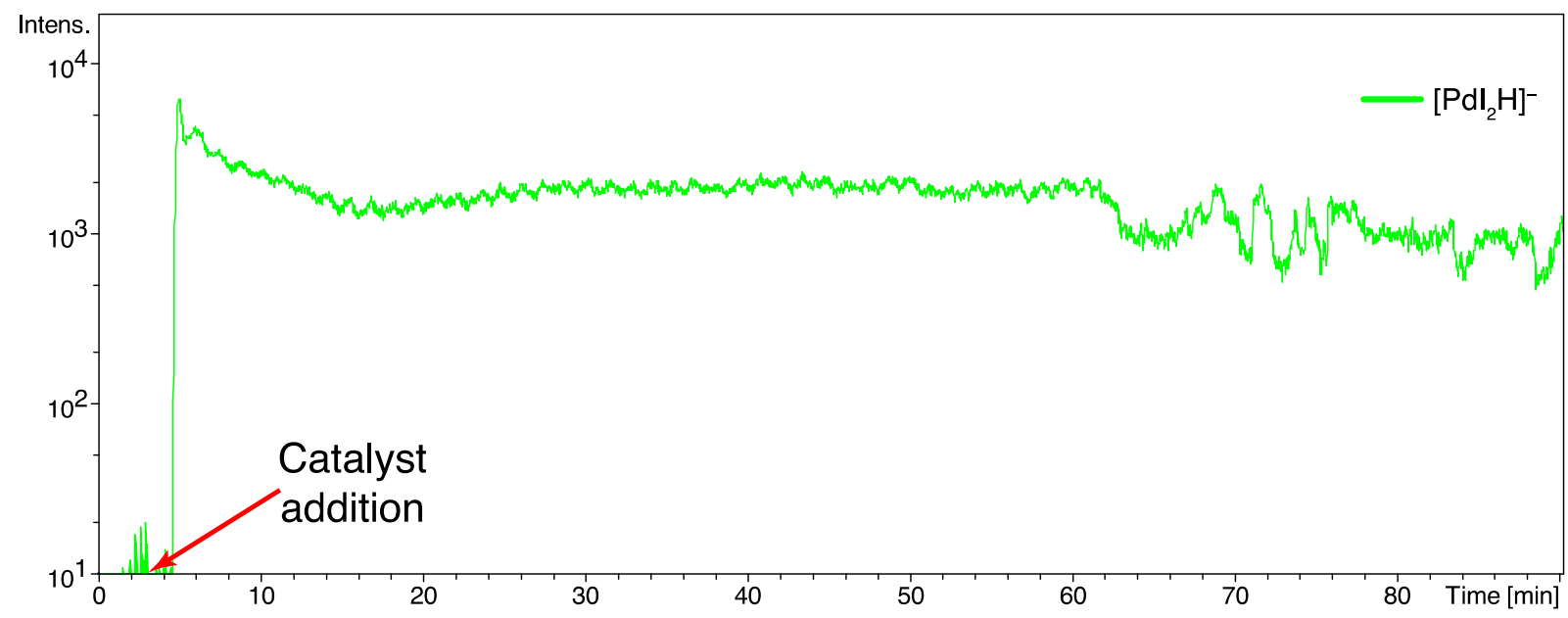

Figure S10. Extracted ion curves for the real-time abundance of ion in the MizorokiHeck reaction between butyl acrylate and iodobenzene in $\mathrm{DMF}\left(\mathrm{K}_{2} \mathrm{CO}_{3}\right.$ as base) catalyzed by $\mathrm{Pd}_{2} \mathrm{dba}_{3}(0.44 \mathrm{~mol} \%)$ (Table 2, Entry 3$)$.

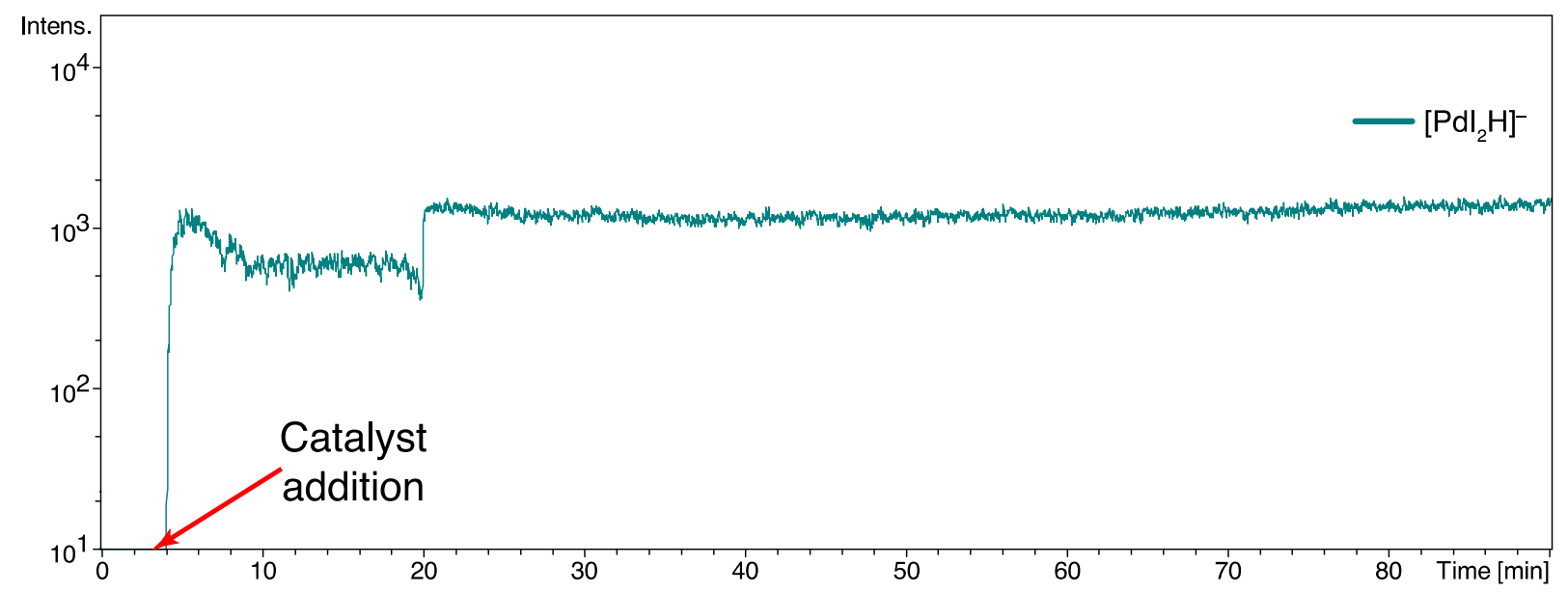

Figure S11. Extracted ion curves for the real-time abundance of ion in the MizorokiHeck reaction between butyl acrylate and iodobenzene in DMF $\left(\mathrm{K}_{2} \mathrm{CO}_{3}\right.$ as base) catalyzed by $\mathrm{Pd}(\mathrm{OAc})_{2}(0.44 \mathrm{~mol} \%)$ (Table 2, Entry 4).

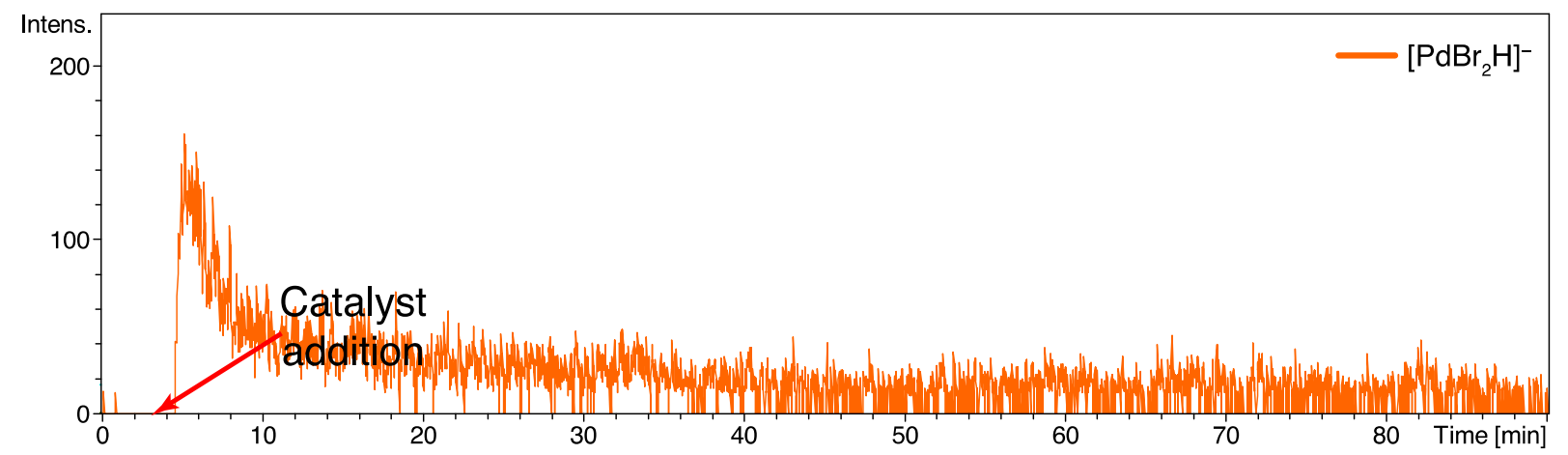

Figure S12. Extracted ion curves for the real-time abundance of ion in the MizorokiHeck reaction between butyl acrylate and bromobenzene in DMF $\left(\mathrm{K}_{2} \mathrm{CO}_{3}\right.$ as base) catalyzed by $\mathrm{Pd}_{2} \mathrm{dba}_{3}(0.44 \mathrm{~mol} \%)$ (Table 2, Entry 7$)$. 


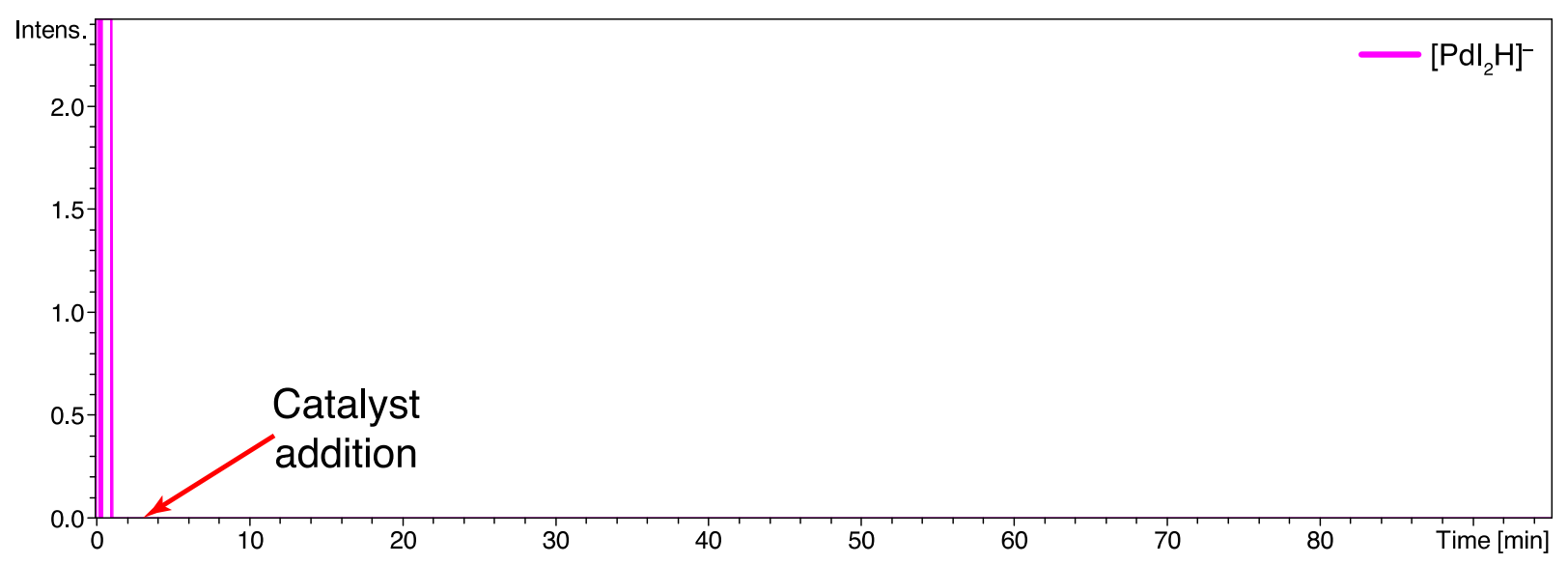

Figure S13. Extracted ion curves for the real-time abundance of ion in the MizorokiHeck reaction between butyl acrylate and iodobenzene in toluene $\left(\mathrm{K}_{2} \mathrm{CO}_{3}\right.$ as base) catalyzed by $\mathrm{Pd}_{2} \mathrm{dba}_{3}(0.44 \mathrm{~mol} \%$ ) (Table 2, Entry 9$)$. 


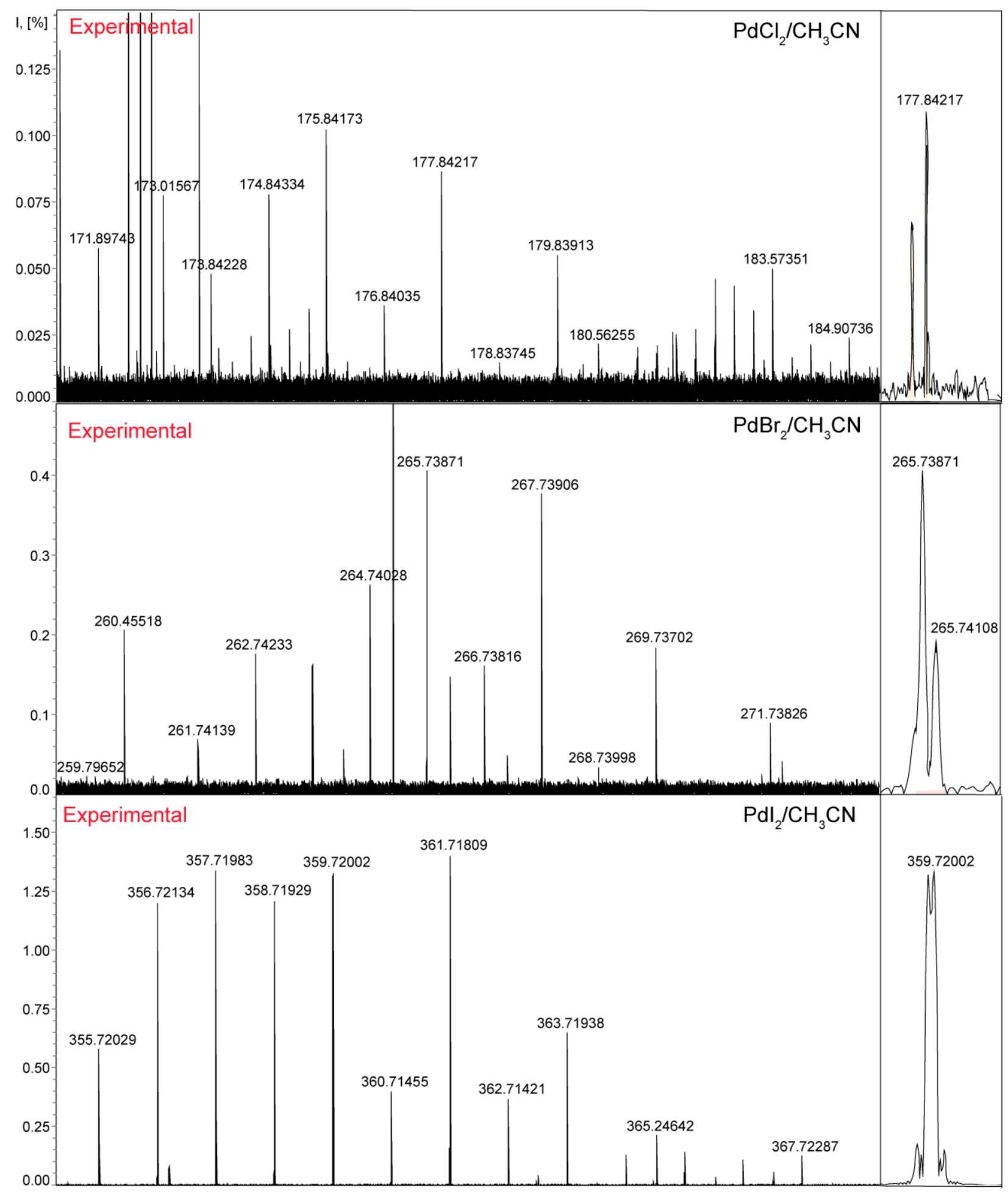

Figure S14. Mass spectra of $\mathrm{PdX}$ solutions in $\mathrm{CH}_{3} \mathrm{CN}$ 


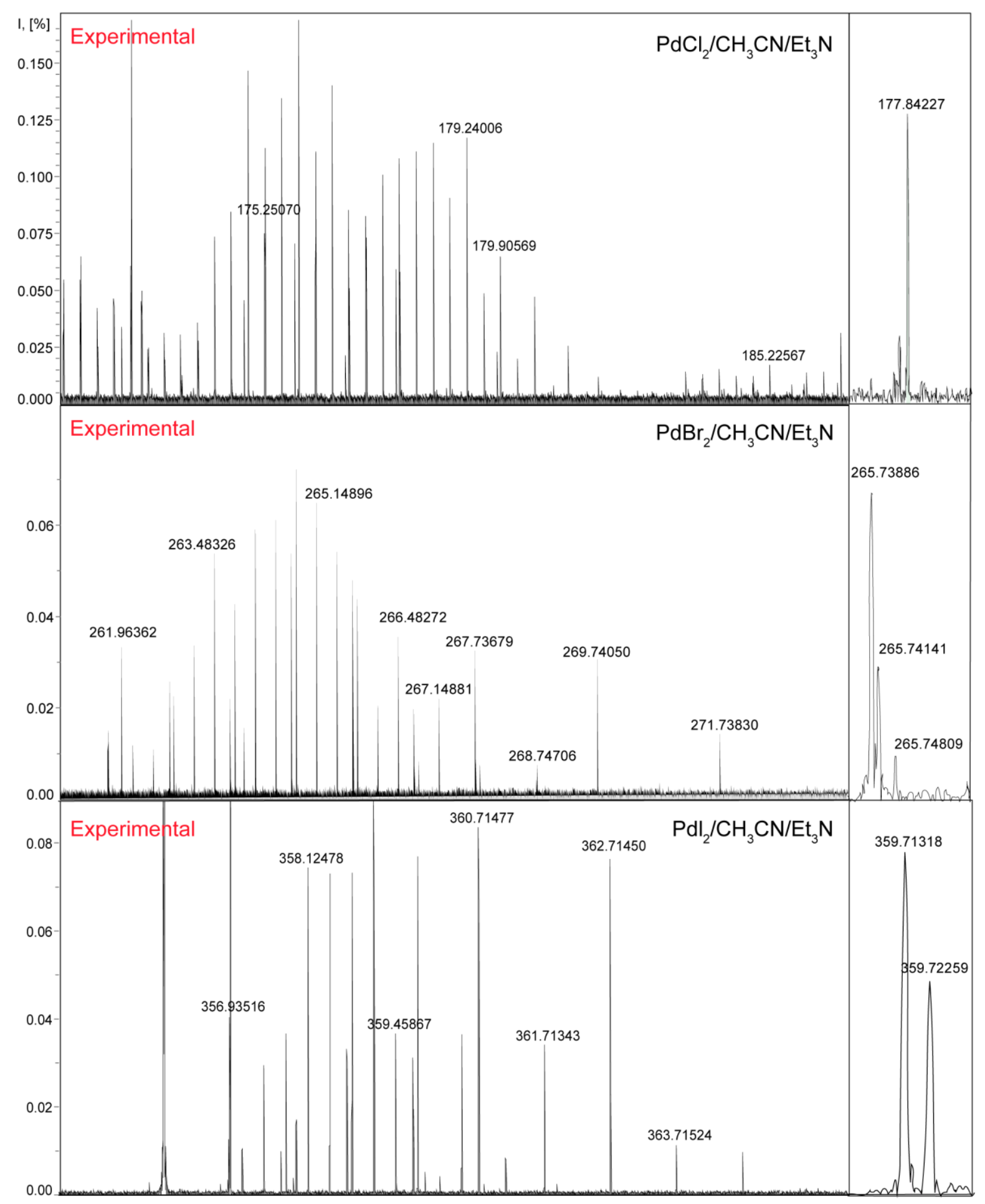

Figure S15. Mass spectra of $\mathrm{PdX}$ solutions in $\mathrm{CH}_{3} \mathrm{CN}$ with $10 \mathrm{eq} \mathrm{Et}_{3} \mathrm{~N}$ 


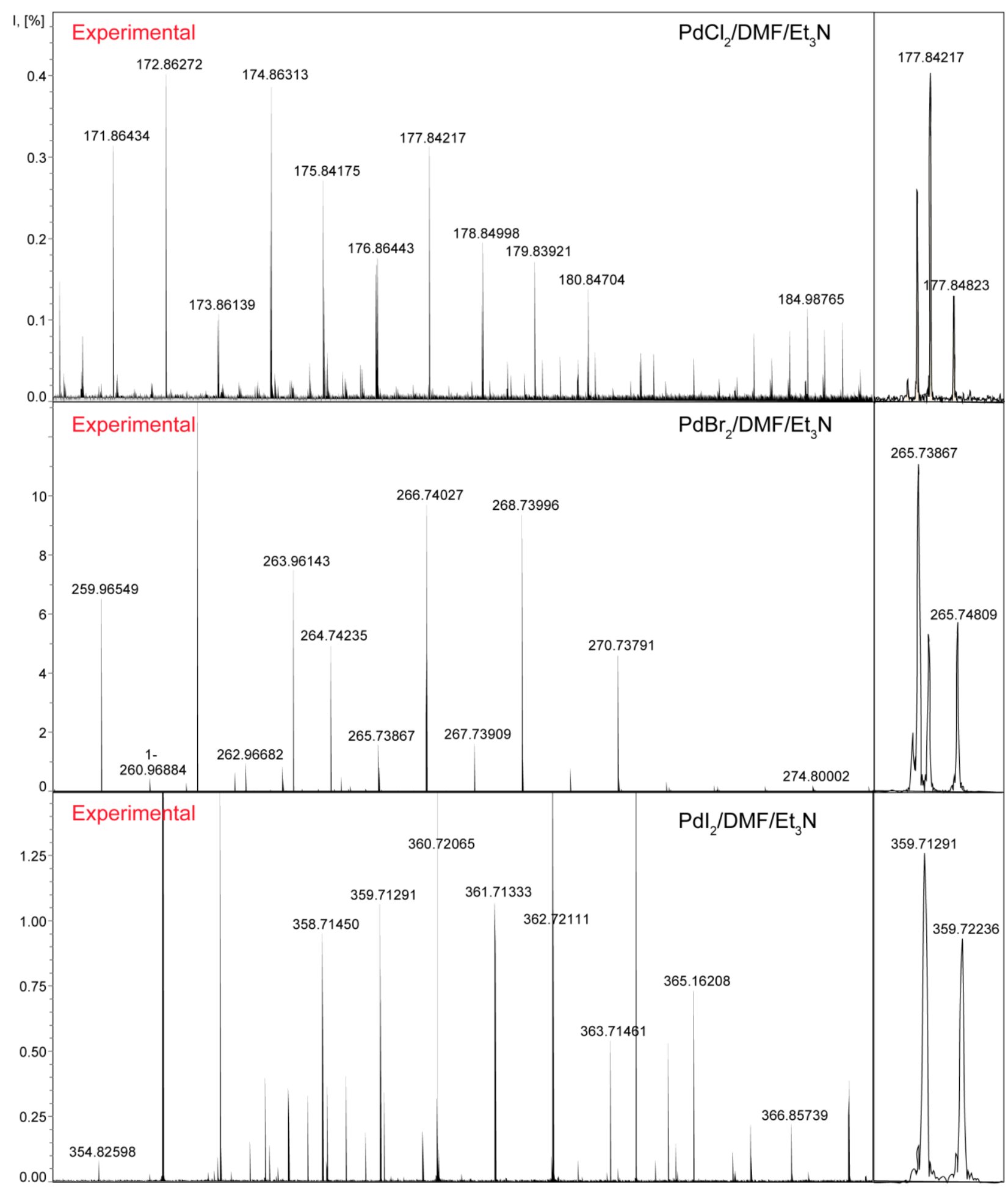

Figure S16. Mass spectra of $\mathrm{PdX}_{2}$ solutions in DMF with $10 \mathrm{eq} \mathrm{Et}_{3} \mathrm{~N}$ 


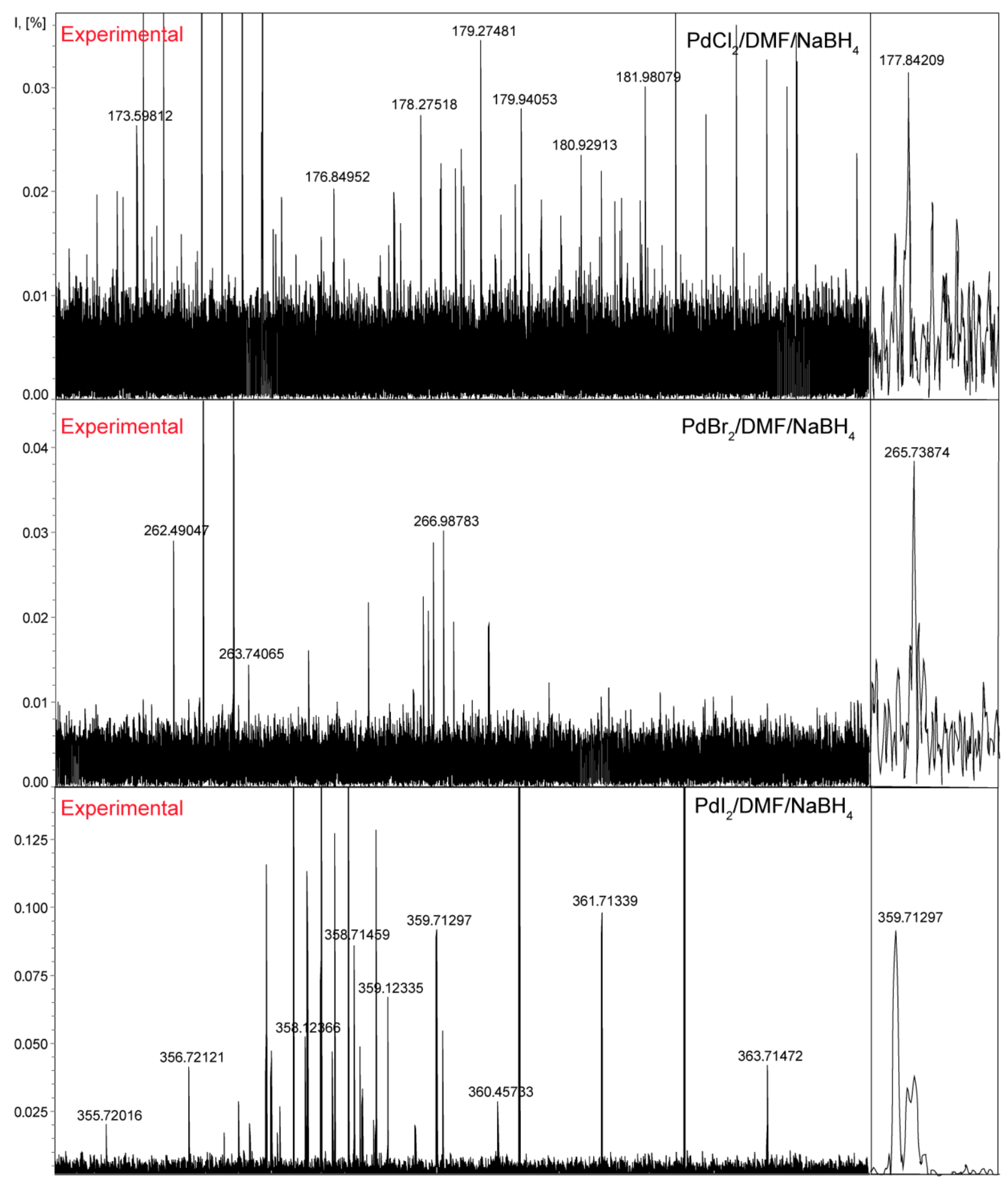

Figure S17. Mass spectra of $\mathrm{PdX}_{2}$ solutions in DMF with 1eq $\mathrm{NaBH}_{4}$ 


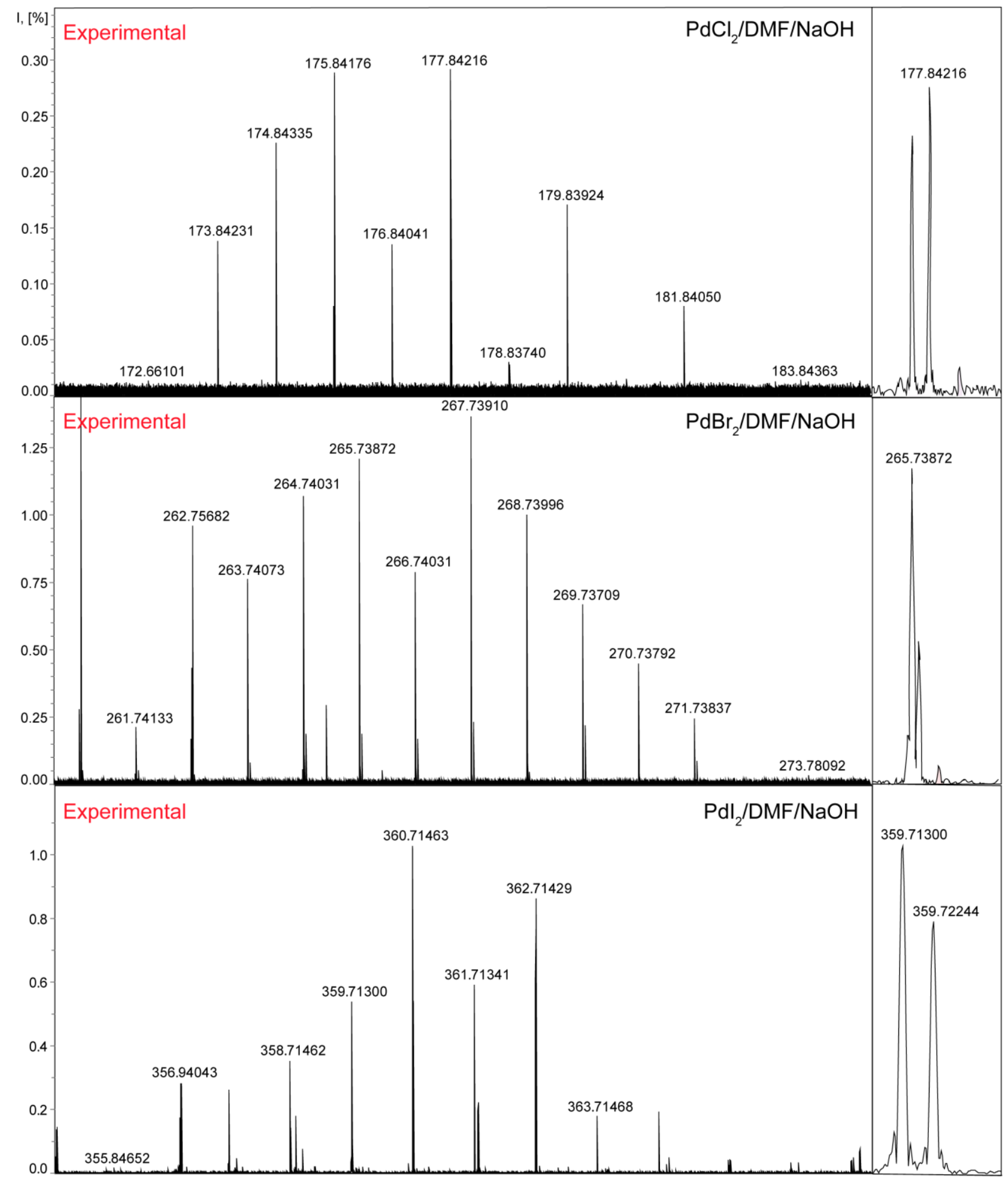

Figure S18. Mass spectra of $\mathrm{PdX}_{2}$ solutions in $\mathrm{DMF}$ with $\mathrm{NaOH}$ 


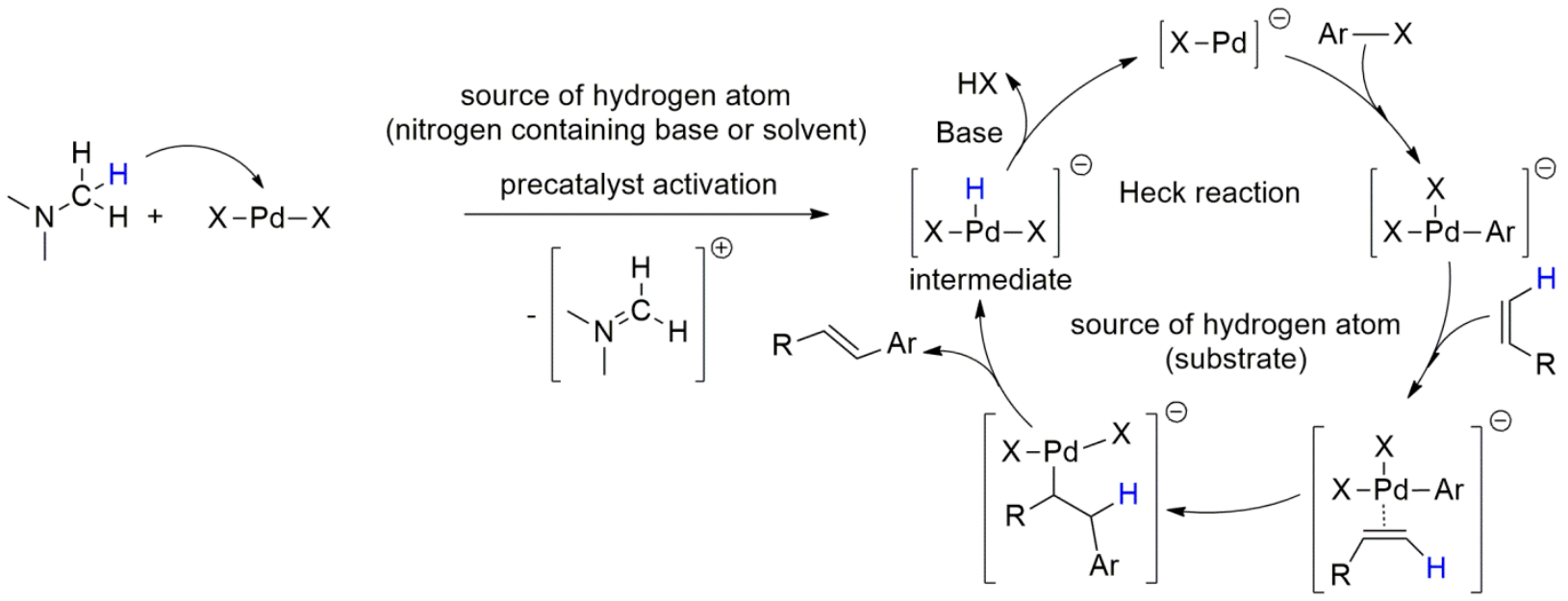

Figure S19. Sources of the hydrogen atom in the process of activation of the precatalyst and in the Heck reaction 